\title{
NGHIÊN CÚU SO SÁNH KẾT QUẢ TUẦ HOÀN NGOÀI CƠ THỂ GIƯ⿱A HAI KIỂU Hệ THỐNG KÍN VÀ HỞ TRÊN BỆNH NHÂN PHẪU THUẬT CẦU NỐI ĐộNG MẠCH VÀNH
}

\author{
Đoàn Đức Hoằng , Bùi Đức Phú, Đặng Thế Uyên ",Bùi Đức Vinh ${ }^{*}$, Đoàn Chí Hiè̀n ${ }^{* *}$
}

\section{TÓM TÁ̀T}

Muc đích: Nghiên cứu so sánh hai kiểu tuần hoàn ngoài cơ thể:

- Kiểu tuần hoàn ngoài cơ thể thường qui với hệ thống hở và không có xử lý lượng máu hút về từ phẫu trường,

- Kiểu tuần hoàn ngoài cơ thể với hệ thống kín nhằm làm giảm bề mặt tiếp xúc khí - máu và có xử lý lượng máu hút về từ phẫu trường.

Phương pháp: Nghiên cứu tiến cứu, ngẫu nhiên, so sánh kết quả áp dụng của 2 kiểu hệ thống tuần hoàn ngoài cơ thể ở 30 bệnh nhân phẫu thuật cầu nối động mạch vành chia làm 2 nhóm:

- Nhóm tuần hoàn ngoài cơ thể kiểu hệ thống hở thường qui $(\mathrm{n}=15)$;

- Nhóm tuần hoàn ngoài cơ thể kiểu hệ thống kín cải tiến $(\mathrm{n}=15)$.

Kết quả:

- Các bệnh nhân phẫu thuật cầu nối động mạch vành giữa 2 nhóm tuần hoàn kiểu hở và nhóm tuần hoàn kiểu kín là không có khác biệt lớn về độ tuổi (65 \pm 8 so với $66 \pm 9$ tuổi);giới tính nam/nữ (14/1 so với 14/1); hematocrit trước mổ $(38,8 \pm 2,7$ so với $38,6 \pm 2,8$ \%). Các đặc điểm kỹ thuật về tuần hoàn ngoài cơ thể và phẫu thuật thực hiện trên 2 nhóm bệnh nhân là khá tương đồng về thời gian cặp động mạch chủ (52 \pm 15 so với $45 \pm 14$ phút); thời gian tuần hoàn ngoài cơ thể ( $90 \pm 28$ so với $74 \pm 23$ phút); thời gian phẫu thuật ( $295 \pm 45$ so với $268 \pm 35$ phút); và số lượng cầu nối chủ-vành $(2,5 \pm 0,6$ so với $2,2 \pm 0,4$ cầu nối).

- Có sự khác biệt rõ về các kết quả như lượng máu truyền sau mổ $(0,9 \pm 1,8$ so với $0,4 \pm 0,8$ đơn vị, $\mathrm{p}<0,01)$; cải thiện phản ứng viêm sau tuần hoàn hoàn cơ thể vớigiảm nồng độ các chất PS100 $(0,7 \pm 1,2$ so với $2,4 \pm 1,8 \mathrm{mcg} / \mathrm{L}, \mathrm{p}<0,001) ; \mathrm{CRP}$ $(173,1 \pm 65,5$ so với $189,1 \pm 60,3 \mathrm{mg} / \mathrm{L}, \mathrm{p}<0,001)$; C3a (1356 634 so với $1785 \pm 1000 \mathrm{gg} / \mathrm{L}, \mathrm{p}<0,001)$;

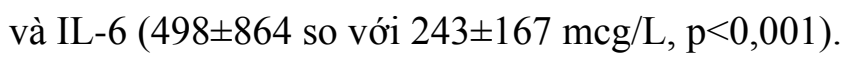

- Kết quả lâm sàng thu được là khác biệt có ý nghĩa thống kê về thời gian thở máy $(5,9 \pm 2,0$ so với $5,2 \pm 1,2$ giờ, $\mathrm{p}<0,01)$; thời gian ICU ( $66 \pm 35$ so với $57 \pm 30, \mathrm{p}<0,009)$; và thời gian nằm viện $(10 \pm 3$ so với $8 \pm 2, \mathrm{p}<0,0009)$.

Kết luận: So với kỹ thuật tuần hoàn ngoài cơ thể thường qui kiểu hệ thống hở, thìtuần hoàn ngoài cơ thểvới hệ thống kín được sử dụng với mục đích làm giảm đáp ứng viêm và các hậu quả của nó, do đó cải thiện chất lượngđiều trị ở các bệnh nhân sau mổ bắc cầu nối chủ-vành với giảm thời gian thở máy, thời gian ICU, và rút ngắn thời gian nằm viện.

\section{CLINICAL COMPARISON OFTWO TYPES OF CARDIOPULMONARY BYPASS: OPEN CIRCUIT VERSUS CLOSE CIRCUIT APPLICATIONIN CORONARY SURGICAL PATIENTS}

Abstract

Purpose: Comparative study of 2 techniques of cardiopulmonary bypass (CPB):

- Technique of open circuit without treatment of blood aspirated from surgical field;

- Technique of close circuit with treatment of

* Bệnh viện Trung uoong Hué

** Sở Y tế TP Hué

Người chịu trách nhiệm khoa hoc: GS.TS. Bùi Đức Phú

Ngày nhận bài: 05/04/2016 - Ngày Cho Phép Đăng: 05/05/2016

Phản Biện Khoa học: PGS.TS. Đặng Ngọc Hùng

GS.TS. Lê Ngoc Thành 
air - blood surface reduction and blood aspirated from surgical field.

Method: This was a clinical prospective, randomized, comparative study in application of open circuit and close circuittechniques in cardiopulmonary bypass in 30 patients undergoing coronary artery bypass graft dividing in 2 groups:

- Conventional open circuit group $(n=15)$;

- Modified close circuit group $(\mathrm{n}=15)$.

Results:

- There were not significantly the differences between open circuit and close circuit groups in patient's age $(65 \pm 8$ vs $66 \pm 9$ years old); male / female (14/1 vs 14/1); pre-op hematocrit $(38,8 \pm 2,7$ vs $38,6 \pm 2,8 \%)$.

- The parameters in CPB technique and surgical intervention of 2 groups were moderately similar in aortic clamp duration $(52 \pm 15 \quad v s 45 \pm 14$ min); CPB duration ( $90 \pm 28$ vs $74 \pm 23$ min); surgery duration(295 \pm 45 vs $268 \pm 35 \mathrm{~min})$; and numbers of CABG $(2,5 \pm 0,6$ vs 2,2 $\pm 0,4$ grafts $)$.

- There were significantly differences in transfusion $(0,9 \pm 1,8$ vs $0,4 \pm 0,8$ units, $\quad \mathrm{p}<0,01)$; improved inflammatory response after $\mathrm{CPB}$ with reduction of serum substances such as PS100 $(0,7 \pm 1,2 \quad$ vs $\quad 2,4 \pm 1,8 \quad \mathrm{mcg} / \mathrm{L}, \quad \mathrm{p}<0,001) ; \quad \mathrm{CRP}$ $(173,1 \pm 65,5$ vs $189,1 \pm 60,3 \mathrm{mg} / \mathrm{L}, \quad \mathrm{p}<0,001) ; \mathrm{C} 3 \mathrm{a}$ (1356 \pm 634 vs $1785 \pm 1000 \mathrm{ng} / \mathrm{L}, \mathrm{p}<0,001)$; and IL-6 (498 \pm 864 vs $243 \pm 167 \mathrm{mcg} / \mathrm{L}, \mathrm{p}<0,001)$.

- There were significantly differences in clinical outcomes of 2 groups in ventilation duration $(5,9 \pm 2,0$ vs $5,2 \pm 1,2 ; \mathrm{p}<0,01)$; ICU time $(66 \pm 35$ vsi $57 \pm 30, \quad \mathrm{p}<0,009)$; and period of hospitalization ( $10 \pm 3$ vs $8 \pm 2, \mathrm{p}<0,0009)$.

Conclusion: In comparison with the CPB open circuit technique, the $\mathrm{CPB}$ close circuit technique applied with the aim to reduce the inflammatory response and its consequence, and then enable us to improve on quality of treatment in CABG patients such as reduction of ventilation duration, ICU time and period of hospitalization.

\section{I. ĐẶT VẤN ĐỀ}

Sự phát triển của phẫu thuật tim thế giới đã có nhiều thành tựu lớn nhờ có nhiều tiến bộ về kỹ thuật mổ, sự phát triển về các phương tiện chẩn đoán, những tiến bộ về kỹ thuật tuần hoàn ngoài cơ thể, gây mê hồi sức sau mổ. Những tiến bộ về kỹ thuật tuần hoàn ngoài cơ thể, trong đó, đặc biệt là những cải tiến trong xử lý lượng máu hút về từ phẫu trường và xử lý bề mặt tiếp xúc giữa khí và máu trong quá trình phẫu thuật giúp khắc phục những hậu quả của sự hoạt hóa máu khi tiếp xúc với bề mặt nhân tạo, nhất là hậu quả của phản ứng viêm do tuần hoàn ngoài cơ thể.Sự hoạt hóa máu trong tuần hoàn ngoài cơ thể xảy ra từ pha tiếp xúc giữa máu với bề mặt nhân tạo nổi bật với sự hấp thu các phân tử protein lên các bề mặt; sự hoạt hóa các yếu tố đông máu theo các con đường nội sinh và ngoại sinh điển hình với thác phản ứng đông máu. Ngoài ra, sự hoạt hóa các thành phần của hệ thống bổ thể là một trong những yếu tố chính gây hậu quả có hại xảy ra trong và sau quá trình tuần hoàn ngoài cơ thể.

Phẫu thuật tim hở đòi hỏi tuần hoàn ngoài cơ thể là một kỹ thuật hỗ trợ chức năng tim và phổi một cách tạm thời đồng thời phải hút máu đảm bảo các thao tác ngoại khoa trên một quả tim ngừng đập tạm thời và phẫu trường sạch máu để có thể sữa chữa các thương tổn trên tim. Do đó, toàn bộ máu trong cơ thể người bệnh sẽ qua hệ thống tuần hoàn cơ thể và tiếp xúc với các bề mạt nhân tạo làm làm hoạt hóa hàng loạt hiện tượng phi sinh lý như phản ứng viêm toàn thể, các phản ứng về miễn dịch và đông máu. Hậu quả của các quá trình này ảnh hưởng lên các cơ quan như não, tim, phổi, thận, gan, và chức năng đông máu.

Từ những năm 2000, nhiều nhà nghiên cứu trên thế giới đã nghiên cứu cải thiện những hậu quả bất lợi này, trong đó nổi bật là nghiên cứu ứng dụng hệ thống kín trong tuần hoàn ngoài cơ thể nhằm hạn chế bề mặt tiếp xúc $k h i$ - máu, đòng thời nghiên cứ xử lý lượng máu không sinh lý được hút về từ phẫu 
trường.ở Việt Nam, phẫu thuật tim đặc biệt phát triển mạnh từ sau những năm 2000 với hàng nhìn ca mổ tim hở / năm, trong đó có rất nhiều loại hình phẫu thuật tim phức tạp và có thời gian tuần hoàn ngoài cơ thể kéo dài. Mục đích của nghiên cứu này nhằm so sánh kết quả sử dụng 2 kiểu hệ thống kín và hở của kỹ thuật tuần hoàn ngoài cơ thể trong phẫu thuật điều trị bệnh lý động mạch vành.

\section{PHƯƠNG PHÁP NGHIÊN CÚU}

\section{1 Đối tượng nghiên cứu}

Nghiên cứu tiến cứu, ngẫu nhiên và so sánh trên 30 bệnh nhân được phẫu thuật tái tạo tưới máu động mạch vành dưới tuần hoàn ngoài cơ thể được chia làm 2 nhóm:

- Nhóm THNCT thường qui với hệ thống hở $(n=15)$ : là hệ thống THNCT với bể chứa máu tĩnh mạch cứng. toàn bộ máu cơ thể người bệnh và lượng máu từ phẫu thuật được dẫn lưu trực tiếp về trong bể chữa máu tĩnh mạch và không qua xử lý rửa máu bởi hệ thống cell saver.

- Nhớm THNCT với hệ thống kín $(\mathrm{n}=15)$ : là hệ thống THNCT có sử dụng thêm một túi mềm chữa máu tĩnh mạch. Máu tĩnh mạch được dẫn lưu về trong túi này và vì vậy hạn chế được bề mặt khi - máu, đồng thời lượng máu từ phẫu trường được qua xử lý rửa máu bởi hệ thống cell saver và sau đó được truyền trở lại cho bệnh nhân.

\subsection{Các bước tiến hành}

\subsubsection{Tiêu chuẩn chọn bệnh}

- Độ tuổi từ 18 đến 75 tuổi

- Có chỉ định phẫu thuật từ 2 cầu nối động mạch vành trở lên

- Có phân suất tống máu thất trái $\mathrm{EF} \geq 40 \%$

\subsubsection{Tiêu chuẩn lọi trù̀}

- Suy chức năng gan, suy thận

- Thiếu máu trước mổ, $\mathrm{Hb}<9 \mathrm{~g} / \mathrm{dL}$

- Những bệnh nhân trước đó đã phẫu thuật dưới THNCT, hoặc phẫu thuật cấp cứu

\subsubsection{Kỹy thuật tuần hoàn ngoài co thể}

- Priming hệ thống THNCT bằng các dung dịch tinh thể và dung dịch cao phân tử với hydroxyethyl amidon với thể tích sử dụng giống nhau giữa 2 nhóm

- Vận hành tuần hoàn ngoài cơ thể ở $32^{\circ} \mathrm{C}$, với lưu lượng từ $2,2-2,4 \mathrm{lít} / \mathrm{m}^{2} /$ phút, và duy trì huyết áp từ $60-90 \mathrm{mmHg}$.

- Kháng đông toàn thân với heparin liều $300 \mathrm{UI} / \mathrm{kg}$ để đạt $\mathrm{ACT} \geq 400$ giây.

- Trung hòa heparin sau khi tháo gỡ các cannula bởi protamine với liều tương đương.

- Bảo vệ cơ tim trong thời gian cặp động mạch chủ theo kỹ thuật xuôi dòng bằng dung dịch liệt tim tinh thể giàu kali sau mỗi 30 phút và theo dõi sự hoạt động trở lại của điện tim.

- Điều trị chống tiêu sợi huyết với acid tranexamic $60 \mathrm{mg} / \mathrm{kg}$.

- Kháng sinh dự phòng bằng cefamandole 30 $\mathrm{mg} / \mathrm{kg}$.

\section{3 Đặc điểm lâm sàng}

\subsubsection{Truyền máu}

- Theo dõi lượng máu chảy qua dẫn lưu ở các thời điểm $6 \mathrm{~h}, 24 \mathrm{~h}$ sau khi về phòng hồi sức và ngay trước khi rút các ống dẫn lưu ngực

- Chỉ định truyền hồng cầu khối duy trì hematocrit sau mổ $\geq 30 \%$

- Theo dõi pha loãng máu trong tuần hoàn ngoài cơ thể với tính bilan nước vào và ra

\subsubsection{Tiêu chuẩn rút ống nội khí quản} ngùng thở máy:

- Bệnh nhân tỉnh táo, đẳng nhiệt

- Huyết động ổn định, không hoặc chỉ sử dụng thuốc vận mạch với liều nhỏ

- Không có biểu hiện khó thở, thiếu oxy tổ chức

- Chảy máu qua ống dẫn lưu $<200 \mathrm{ml} /$ trong 4 giờ liên tiếp

- Thời gian thở máy từ khi bệnh nhân về phòng hồi sức cho đến khi rút ống nội khí quản

\subsubsection{Tiêu chuẩn chuyển bệnh nhân ra}

\section{khöi ICU}

- Huyết động ổn định, không cần sử dụng inotrope, không có nhồi máu cơ tim

- Chức năng thận không có thiểu niệu, hệ số 
thanh thải creatinine $>50 \mu \mathrm{mol} / \mathrm{ml} / \mathrm{m}^{2}$, creatinine máu $<200 \mu \mathrm{mol} / \mathrm{L}$

- Thở tự nhiên không cần mask oxy: với $\mathrm{PO}_{2}$ $>65 \mathrm{mmHg}, \mathrm{SpO}_{2}>95 \%$

- Không có rối loạn tri giác và chức năng thần kinh

2.3.4 Thời gian nằm viện, tính theo các tiêu chuẩn xuất viện sau

- Không sốt

- Vết mổ liền sẹo tốt

- Huyết động ổn định, không có rối loạn nhịp, hoặc rối loạn dẫn truyền tiến triển

- Chức năng oxy hóa bình thường, không có tràn dịch màng phổi, tràn dịch màng tim

- Không có rối loạn chuyển hóa, thiếu máu

\section{4 Đặc điểm cận lâm sàng}

2.4.1 Công thức máu thục hiện ở các thò̀i điểm sau

- Trước phẫu thuật

- 4h sau khi kết thúc THNCT
- Ngày J1, J2, J3, J5 và J5 sau phẫu thuật

2.4.2 Hb tụ do, protein S-100, C3a và IL-6

- Định lượng nồng độ C3a ngay sau khi kết thúc THNCT

- Định lượng nồng độ IL-6 vào 4 giờ sau khi kết thúc THNCT

- Định lượng nồng độ $\mathrm{Hb}$ tự do vào 3 thời điểm sau, 5 phút trước khi rạch da, 5 phút trước khi kết thúc THNCT, 4h sau khi kết thúc THNCT

2.4.3 Protein $\mathrm{C}$ phản ứng định lượng vào các thời điểm sau5 phút trước khi rạch da, 4 giờ sau khi kết thúc THNCT, Ngày J2 sau mổ

2.4.4 PdF, sản phẩm giáng hóa fibrin đượcđịnh lượng vào các thời điểm 5 phút trước khi rạch da, ngay trước khi kết thúc THNCT, 4 giờ sau khi kết thúc THNCT

2.4.5 Tỷ lệ $\mathrm{PaO}_{2} / \mathrm{FiO}_{2}$, chỉ số oxy hóa được đo để đánh giá quá trình trao đổi khí5 phút trước khi rạch da, Ngay sau khi kết thúc THNCT, theo dõi bão hòa oxy máu ngoại vi $\mathrm{SpO}_{2}$

\section{KÊT QUẢ NGHIÊN CÚU}

\section{1 Đặc điểm nhóm nghiên cứu}

Bảng 3.1 đặc điểm của nhóm nghiên cúu

\begin{tabular}{|l|c|c|}
\hline \multicolumn{1}{|c|}{ Đặc điểm } & Hệ thống hở & Hệ thống kín \\
\hline Tuổi trung bình (năm) & $65 \pm 8$ & $66 \pm 9$ \\
\hline Tỷ lệ giới tính (nam/nữ) & $14 / 1$ & $14 / 1$ \\
\hline Diện tích cơ thể & $1,58 \pm 0,1$ & $1,60 \pm 0,12$ \\
\hline Hematocrit trước mổ & $38,8 \pm 2,7$ & $38,6 \pm 2,8$ \\
\hline Thời gian cặp động mạch chủ & $52 \pm 15$ & $45 \pm 14$ \\
\hline Thời gian tuần hoàn ngoài cơ thể & $90 \pm 28$ & $74 \pm 23$ \\
\hline Thời gian phẫu thuật & $295 \pm 45$ & $268 \pm 35$ \\
\hline Số lượng cầu nối chủ - vành & $2,5 \pm 0,6$ & $2,2 \pm 0,4$ \\
\hline
\end{tabular}

Nhân xét:

- Hai nhóm bệnh nhân nghiên cứu tương đồng về độ tuổi, tỉ lệ giới tính, diện tích cơ thể, thời gian phẫu thuật, thời gian cặp động mạch chủ, thời gian THNCT và số lượng cầu nối chủ vành thực hiện trên các bệnh nhân.

- Tỷ lệ giới tính (nam / nữ) trong cả 2 nhóm biểu thị nam giới mắc bệnh động mạch vành nhiều hơn so với nữa giới. 
3.2 Đặc điểm lâm sàng

3.2.1 Thời gian thở máy, thời gian ICU, thời gian nằm viện

Bảng 3.2 Thời gian thở máy, thời gian ICU, thời gian nằm viện

\begin{tabular}{|l|c|c|c|c|}
\hline \multicolumn{1}{|c|}{ Thông số } & $\begin{array}{c}\text { Chung } \\
(\mathbf{n = 3 0})\end{array}$ & $\begin{array}{c}\text { Hệ thống hở } \\
(\mathbf{n = 1 5})\end{array}$ & $\begin{array}{c}\text { Hệ thống kín } \\
(\mathbf{n = 1 5})\end{array}$ & P \\
\hline Thời gian thở máy (giờ) & $5,3 \pm 1,7$ & $5,9 \pm 2,0$ & $5,2 \pm 1,2$ & $\mathrm{p}<0,01$ \\
\hline Thời gian ICU (giờ) & $55 \pm 27$ & $66 \pm 35$ & $57 \pm 30$ & $\mathrm{p}<0,009$ \\
\hline Thời gian nằm viện & $8,6 \pm 1,9$ & $10 \pm 3,0$ & $8 \pm 2,0$ & $\mathrm{p}<0,0009$ \\
\hline
\end{tabular}

Nhân xét:

- Thời gian thở máy trung bình chung cả 2 nóm nghiên cứu là $5,3 \pm 1,7$ giờ

- Thời gian điều trị ICU của nhóm THNCT kiểu hệ thống hở là $66 \pm 35$ giờ, dài hơn có ý nghĩa thống kê so với nhóm còn lại. Kết quả tương tự đối với thời gian nằm viện, đó là những kết quả thuận lợi của nhóm THNCT kiểu hệ thống kín

\subsection{2 Đặc điểm chảy máu sau mổ}

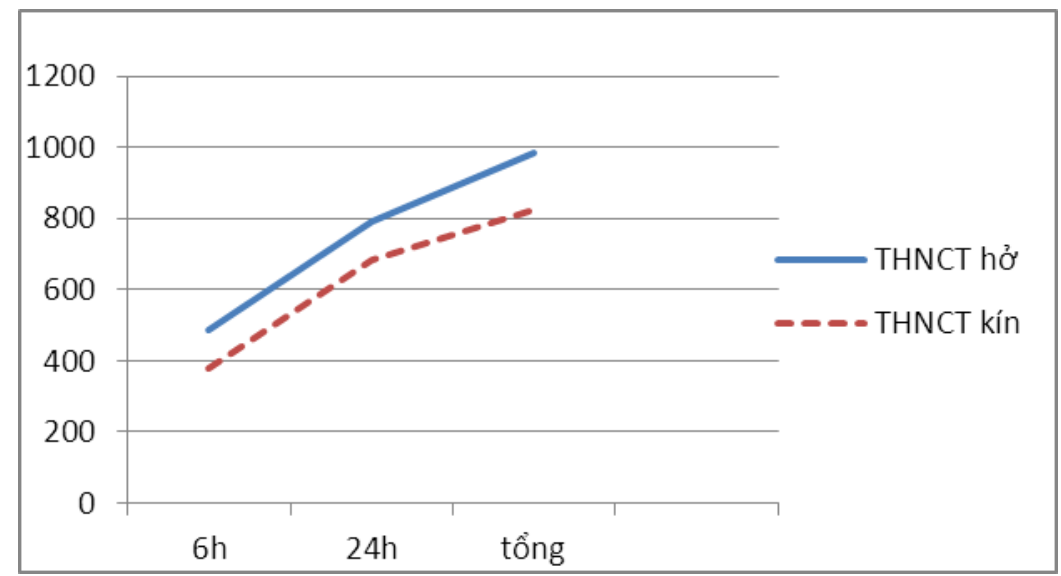

Biểu đồ 3.1 so sánh lương máu chảy sau mổ giữa 2 nhóm nghiên cúu

Nhân xét:

- Lượng máu chảy sau mổ ở nhóm THNCT kiểu hệ thống hở nhiều hơn so với nhóm THNCT kiểu hệ thống kín theo dõi qua các khoảng thời gian 6 giờ đầu và 24 giờ đầu sau mổ, cho đến khi rút óng dẫn lưu ngực.

\subsection{3 Đặc điểm pha loãng máu trong THNCT}

Bảng 3.3 Bilan dịch vào và bilan dịch ra trong THNCT

\begin{tabular}{|l|c|c|c|}
\hline \multicolumn{1}{|c|}{ Thông số } & $\begin{array}{c}\text { Hệ thống } \\
\text { hở(n=15) }\end{array}$ & $\begin{array}{c}\text { Hệ thống kín } \\
(\mathbf{n = 1 5})\end{array}$ & P \\
\hline Thể tích priming & $1310 \pm 57$ & $1350 \pm 35$ & $\mathrm{p}<0,01$ \\
\hline Thể tích bù trong THNCT & $410 \pm 316$ & $1076 \pm 653$ & $\mathrm{p}<0,002$ \\
\hline Thể tích dung dịch liệt tim & $1003 \pm 237$ & $896 \pm 275$ & \\
\hline Thể tích dịch truyền trong gây mê & $523 \pm 68$ & $526 \pm 223$ & \\
\hline Thể tích cô đặc (cell saver) & & $733 \pm 326$ & \\
\hline Thể tích thu hồi (cell saver) & & $2045 \pm 855$ & \\
\hline
\end{tabular}




\begin{tabular}{|l|c|c|c|}
\hline Thể tích hút bỏ & $320 \pm 56$ & $385 \pm 248$ & \\
\hline Thể tích nước tiểu & $220 \pm 261$ & $111 \pm 114$ & $\mathrm{p}<0,009$ \\
\hline Thể tích huyết cầu & $27,9 \pm 3,8$ & $30,7 \pm 3,3$ & \\
\hline BILAN & $2736 \pm 330$ & $2213 \pm 888$ & $\mathrm{p}<0,0001$ \\
\hline
\end{tabular}

Nhân xét:

- THNCT kiểu hệ thống kín cần pha loãng máu nhiều hơn đáng kể so với hệ thống hở;

- Thể tích bù trong THNCT kiểu hệ thống kín cũng nhiều hơn có ý nghĩa thống kê;

- Khác với hệ thông hở, THNCT kiểu hệ thống kín có xử lý máu hút về bằng cell saver làm cô đặc máu nên giá trị hematocrit và bilan dịch cuối THNCT thấp hơn khác biệt.

\subsection{4 Đặc điểm truyền máu sau mổ}

Bảng 3.4 Đặc điểm truyền máu sau mổ

\begin{tabular}{|l|c|c|c|}
\hline \multicolumn{1}{|c|}{ Thông số } & $\begin{array}{c}\text { Hệ thống hở } \\
(\mathrm{n}=15)\end{array}$ & $\begin{array}{c}\text { Hệ thống kín } \\
(\mathrm{n}=15)\end{array}$ & $\mathrm{P}$ \\
\hline Số đơn vị hồng cầu khối / 1 bệnh nhân & $0,9 \pm 1,8$ & $0,4 \pm 0,8$ & $\mathrm{p}<0,01$ \\
\hline Số bệnh nhân cần truyền máu & $3,5 \pm 2$ & $2 \pm 0$ & $\mathrm{p}<0,01$ \\
\hline
\end{tabular}

Nhân xét:

- Có sự khác biệt đáng kể về số bệnh nhân cần truyền máu và thể tích trung bình máu truyền cho một bệnh nhân giữa 2 nhóm nghiên cứu.

3.3 Đặc điểm cận lâm sàng

3.3.1 Kết quả các xét nghiệm hóa sinh

Bảng 3.5 Các thông số đánh giá phản úng viêm do THNCT

\begin{tabular}{|c|c|c|c|c|}
\hline Thông số & Thời điểm & $\begin{array}{l}\text { Hệ thống hở } \\
(\mathrm{n}=15)\end{array}$ & $\begin{array}{l}\text { Hệ thống kín } \\
(\mathrm{n}=15)\end{array}$ & $\mathrm{P}$ \\
\hline \multirow{2}{*}{ PS $100(\mu \mathrm{g} / \mathrm{L})$} & Trước rạch da & $0,05 \pm 0,03$ & $0,03 \pm 0,02$ & \\
\hline & Kết thúcphẫu thuật & $2,4 \pm 1,8$ & $0,7 \pm 1,2$ & $<0,001$ \\
\hline \multirow{3}{*}{$\mathrm{CRP}(\mathrm{mg} / \mathrm{L})$} & Trước rạch da & $2,3 \pm 2,5$ & $3,5 \pm 8,9$ & \\
\hline & 4h sau mổ & $2,3 \pm 2,5$ & $3,2 \pm 5,7$ & \\
\hline & Ngày thứ 2 sau mố & $173,1 \pm 65,5$ & $179,1 \pm 60,3$ & \\
\hline \multirow{2}{*}{ C3a (ng/L) } & Trước rạch da & $846 \pm 588$ & $722 \pm 206$ & \\
\hline & Kết thúc THNCT & $1785 \pm 1000$ & $1356 \pm 634$ & $<0,03$ \\
\hline \multirow{2}{*}{ IL-6 $(\mu \mathrm{g} / \mathrm{L})$} & Trước rạch da & 0 & 0 & \\
\hline & 4h sau mổ & $498 \pm 864$ & $243 \pm 167$ & \\
\hline \multirow{3}{*}{$\operatorname{Pdf}(\mu g / L)$} & Trước rạch da & $5,3 \pm 1,3$ & 5 & \\
\hline & Kết thúc THNCT & $7 \pm 4,1$ & 5 & $<0,02$ \\
\hline & 4h sau mố & $6,7 \pm 4,1$ & 5 & $<0,05$ \\
\hline \multirow{3}{*}{$\mathrm{PaO}_{2} / \mathrm{FiO}_{2}$} & Trước rạch da & $327 \pm 170$ & $360 \pm 175$ & \\
\hline & Kết thúc phẫu thuật & $274 \pm 97$ & $288 \pm 108$ & \\
\hline & 4h sau mổ & $245 \pm 117$ & $230 \pm 93$ & \\
\hline
\end{tabular}

Nhân xét: Ở giai đoạn sau mổ, nồng độ tăng khác biệt các yếu tố liên quan đáp ứng viêm như thành phần C3a của bổ thể, Pdf, và PS 100 ở nhóm THNCT kiểu hệ thống hở.

\subsubsection{Kết quả các xét nghiệm huyết học}

\subsubsection{Nồng độ hemoglobin tụ do trong huyết}




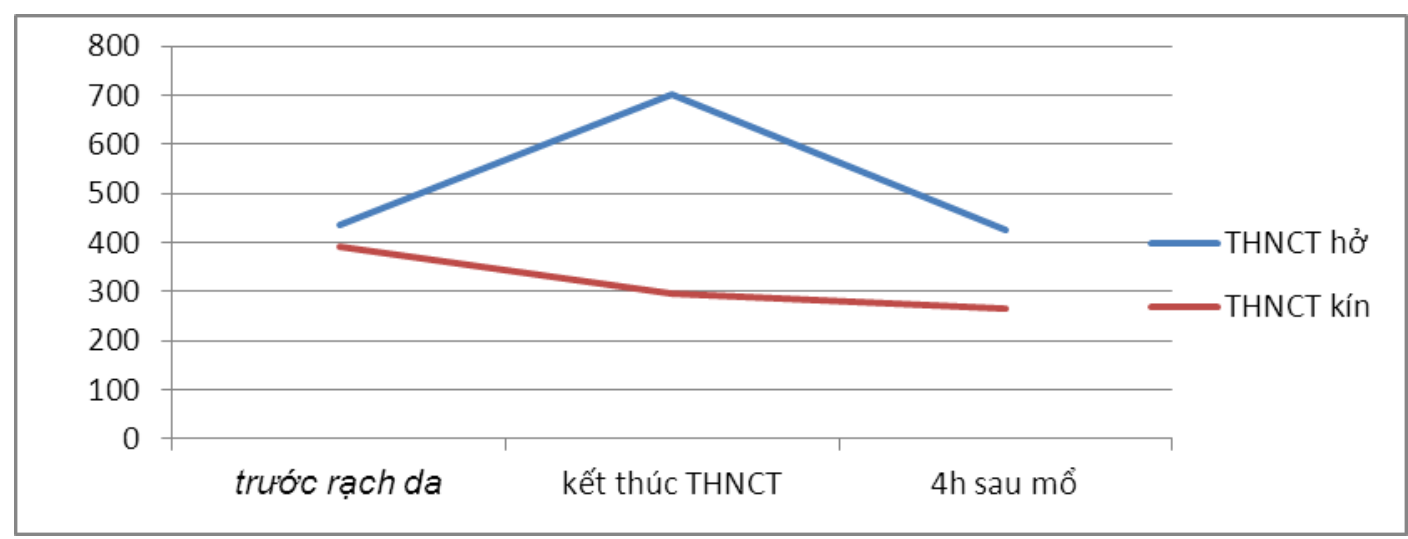

Biểu đồ 3.2 Nồng độ hemoglobin tụ do trong huyết thanh ở 2 nhóm nghiên cứu

Nhân xét: Nồng độ hemoglobin tự do trong huyết thanh ở nhóm THNCT kiểu hệ thống hở tăng cao khác biệt ở các thời điểm sau THNCT và thời điểm $4 \mathrm{~h}$ sau mổ.

\subsubsection{Số lương bạch cầu đa nhân trung tính}

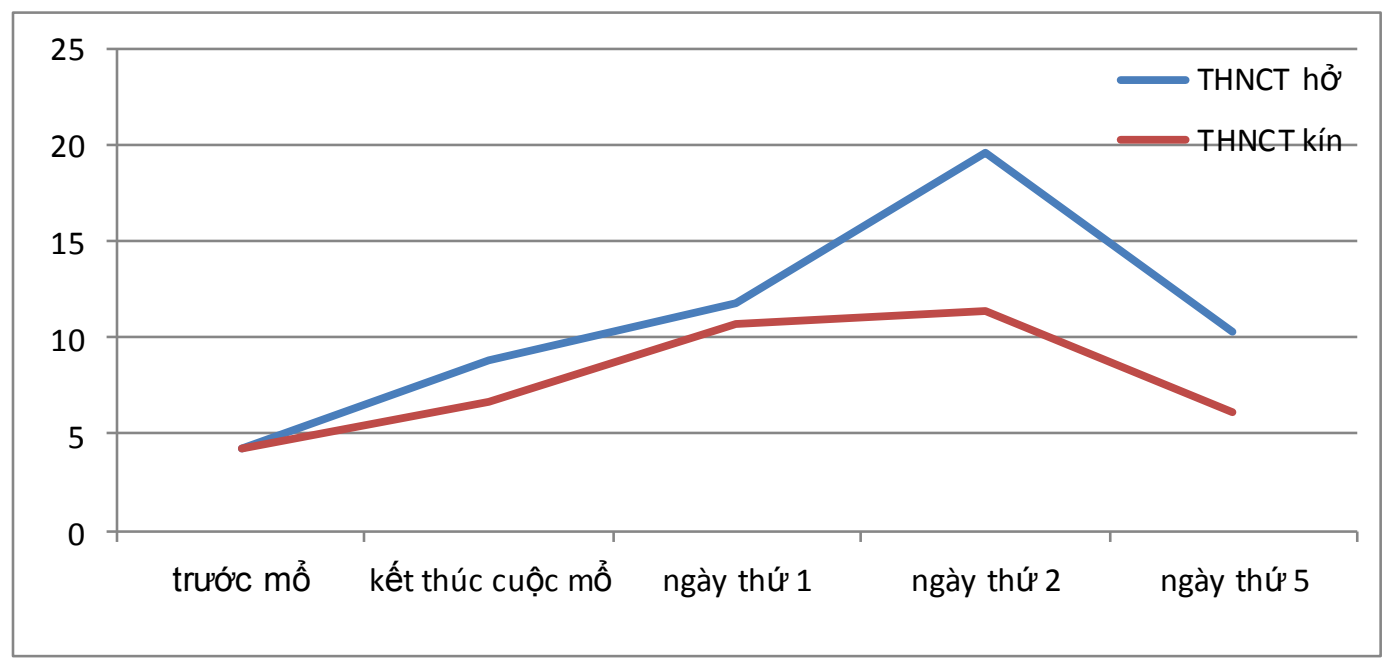

Biểu đồ 3.3 Số lự̣ng bạch cầu đa nhân trung tính của 2 nhóm nghiên cứu

Nhân xét: Bạch cầu đa nhân trung tính tăng khác biệt ở nhóm THNCT kiểu hệ thống hở 3.3.2.3 Chì số oxy hóa $\mathrm{PaO}_{2} / \mathrm{FiO}_{2}$ và $\mathrm{SpO}_{2}$ 


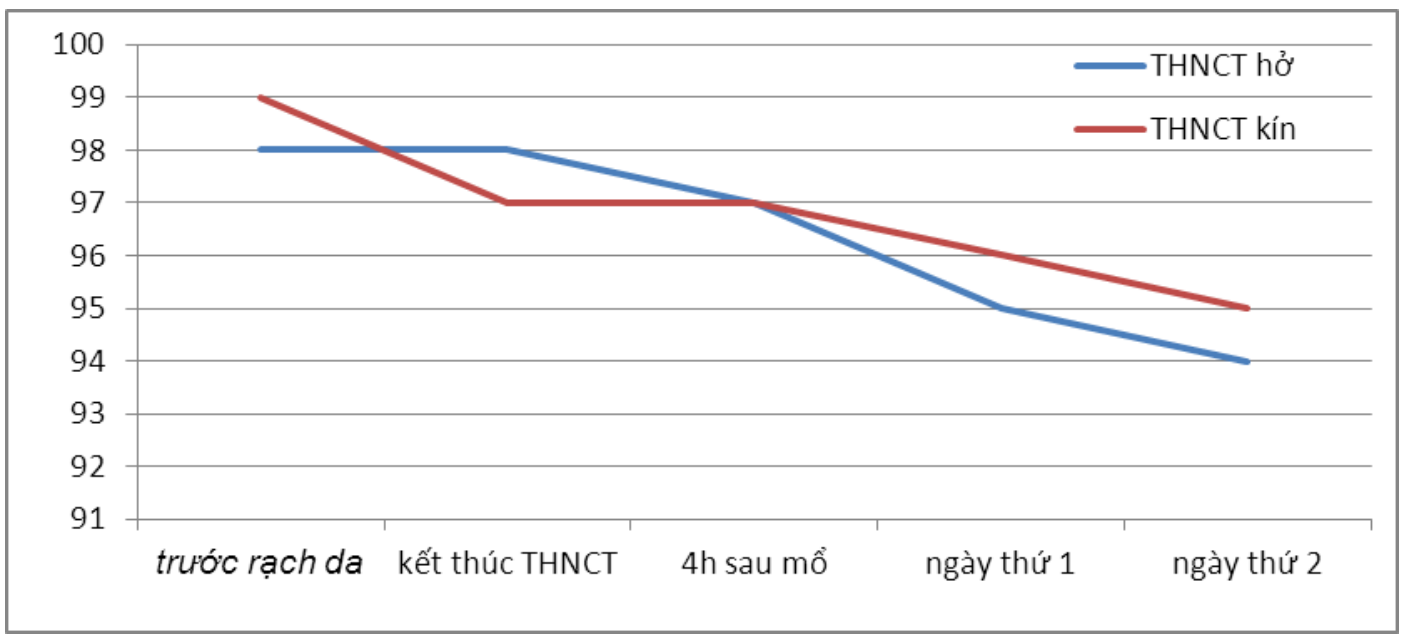

Biểu đồ 3.4 Bão hòa oxy máu ngọi vi $\mathrm{SpO}_{2}$ của 2 nhóm nghiên cứu

Nhân xét: Chỉ số oxy hóa $\left(\mathrm{PaO}_{2} / \mathrm{FiO}_{2}\right)$ là không khác biệt giữa 2 nhóm trong những giờ đầu sau mổ, giá trị $\mathrm{SpO}_{2}$ là cải thiện cao hơn ở nhóm THNCT kiểu hệ thống kín.

\section{BÀN LUẬN}

Trong phẫu thuật tim dưới tuần hoàn ngoài cơ thể, các nguyên nhân gây khởi phát phản ứng viêm và các rối loạn đông máu là rất phức tạp.

\subsection{Phản ứng viêm do tuần hoàn ngoài cơ thể}

- Ngay từ khi bắt đầu quá trình phẫu thuật, các thao tác ngoại khoa như rạch da, phẫu tích gỡ dính, làm bộc lộ trong khoảng thời gian dài các mô cơ quan với môi trường bên ngoài làm khởi phát hiện tượng viêm xảy ra trong cơ thể người bệnh.

- Đầu tiên, nồng độ C3a tăng cao ngay trước khi bắt đầu phẫu thuật. điều này được giải thích do stress tâm lý gây hoạt hóa chuỗi phản ứng bổ thể.Ngoài ra, nồng độ C3a ở nhóm THNCT kiểu hệ thống hở tăng cao hơn ở nhóm THNCT kiểu hệ thống kín.

- Chúng tôi nhận thấy số lượng bạch cầu đa nhân trung tĩnh tăng rất cao vào ngày thứ 2 sau mổ ở nhóm THNCT kiểu hệ thống hở. tỷ lệ bạch cầu đều tang ở cả 2 nhóm là đặc tính của phản ứng viêm do phẫu thuật và do tuần hoàn ngoài cơ thể.

- Nồng độ interleukin-6 tăng cao hơn ở nhóm THNCT kiểu hệ thống hở. một nghiên cứu khác về
THNCT kiểu hở có hoặc không có xử lý máu hút về từ phẫu trường cũng cho thấy giảm nồng độ interleukin-6 bởi sử dụng hệ thống cell saver.

- THNCT kiểu hệ thống kín hạn chế được bề mặt tiếp xúc khí - máu là nguồn gốc làm giảm sự hoạt hóa đáp ứng viêm và sự đông máu với sự khác biệt giảm hẳn nồng độ các chất tham gia vào quá trình viêm nêu ở trên. Tuy nhiên, tĩnh phức tạp của kỹ thuật mổ tim phụ thuộc rất nhiều yếu tố khác nhau cho nên thạt khó để xác định mức độ tác động của mỗi yếu tố gấy khởi phát đáp ứng viêm này. Tuy nhiên, với THNCT kiểu hệ thống kín ta có thể xác đinh được vai trò quan trọng của việc xử lý lượng máu hút về từ phẫu trường góp phần làm giảm phản ứng viêm.

\subsection{Nồng độ hemoglobin tự do và các sản} phẩm giáng hóa fibrin

- Sử dụng hệ thống cell saver để rửa và cô đặc máu giúp cải thiện chất lượng máu trong hệ thống THNCT khi truyền trở lại cho người bệnh do làm giảm nồng độ các chất như hemoglobin tự do, các sản phẩm giáng hóa fibrin, các yếu tố gây hoạt hóa đông máu, yếu tố mô, các chất béo lắng đọng trong hệ thống THNCT và các nội độc tố. 
- Hemoglobin là bằng chứng của sự gây tán huyết rất nhiều do THNCT kiểu hệ thống hở. trong một nghiên cứu khác đã đưa ra ý kiến về việc xử lý lượng máu hút về từ phẫu trường là yếu tố quan trọng giúp làm giảm nồng độ hemoglobin tự do hình thành từ trong khoang màng tim và trong quá trình hút máu về hệ thống. Nghiên cứu củaAldea GS cũng đã nêu ra THNCT kiểu hệ thống kín hạn chế bề mặt tiếp xúc khí - máu do đó giúp làm giảm hiện tượng tán huyết.

\subsection{Nồng độ protein $\mathrm{S}-100$}

- Nồng độ protein S-100 tăng cao ở nhóm THNCT kiểu hệ thống hở có lẽ do PS-100 là yếu tố rất nhạy cảm với các thuyên tắc vi bọt khí. Giai đoạn sau mổ mạch vành dưới tuần hoàn ngoài cơ thể kiểu hệ thống hở, PS-100 sản xuất từ các khoang thần kinh, từ các tế bào tạo mỡ, tế bào tủy xương lắng đọng trong khoang màng ngoài tim. Việc định lượng nồng độ $\mathrm{PS}-100$ vào thời điểm $12 \mathrm{~h}$ đầu sau mổ tim là có ý nghĩa nhất.

- Sử dụng hệ thống cell saver giúp loại bỏ các chất được tạo bởi từ lượng máu đọng trong khoang màng ngoàitim vốn là mội trường để hình thành hàng loạt các dẫn chất gây hoạt hóa các quá trình đông máu và quá trình viêm.

\subsection{Chảy máu và truyền máu}

- Trong nghiên cứu so sánh về mức độ chảy máu giữa 2 nhóm THNCT kiểu hệ thống hở và kiểu hệ thống kín, chúng tôi nhận thấy sự khác biệt có ý nghĩa thống kê về các yếu tố thuận lợi của hệ thống kin nhờ có xử lý lượng máu hút về (bảng 3.4), điều này cũng được tìm thấy trong nghiên cứu của Aldea GS.

- Sự trộn lẫn giữa lượng máu hút về từ phẫu trường vào bể chứa máu tĩnh mạch của THNCT kiểu hệ thống hở chính là nguồn gốc gây hoạt hóa phản ứng viêm và các rối loạn đông máu. Ích lợi của việc xử lý máu đọng từ phẫu trường bởi hệ thống cell saver là giảm biến chứng chảy máu sau mổ.

\subsection{Bilan dịch sử dụng trong tuần hoàn} ngoài co thể

- Pha loàng máu trong THNCT làm pha loãng các yếu tố đông máu, làm giảm quá trình vận chuyển oxy do pha loãng hemoglobin, và làm nặng hiện tượng thoát dịch từ lòng mạch vào mô cơ quan do tăng tính thấm mạch máu dẫn đến phản ứng viêm.

- Sử dụng hệ thống kín trong THNCT ở bệnh nhân phẫu thuật mạch vành làm giảm được pha loãng máu và giảm sử dụng thêm dịch trong quá trình THNCT có vai trò đáng kể khắc phục hậu quả thiếu oxy tổ chức và biến chứng chảy máu được quan sát vào ngày thứ 2 sau mổ (bảng 3.5, biểu đồ 3.4).

\section{KẾT LUẬN}

Qua nghiên cứu so sánh và phân tích các hậu quả của THNCT giữa 2 kiểu hệ thống hở và kín như phản ứng viêm, phản ứng bổ thể và rối loạn đông máu ở những bệnh nhân phẫu thuật mạch vành chúng tôi có một số kết luận sau:

- Tuần hoàn ngoài cơ thể kiểu hệ thống kín, giúp hạn chế bề mặt tiếp xúc khí - máu đồng thời kỹ thuật này giúp xử lý được lượng máu hút về từ phẫu trường qua đó hạn chế sự hình thành hoặc loại bỏ được phần lớn các chất như C3a, IL-6, PS-100, Pdf, Hb tự do ... do đó góp phần khắc phục các hậu quả THNCT nói trên.

- Tuần hoàn ngoài cơ thể kiểu hệ thống kín làm giảm phản ứng viêm và các hậu quả có hại cho nên góp phần cải thiện chất lượng phẫu thuật như giảm biến chứng chảy máu, giảm thời gian thở máy, giảm thời gian $\mathrm{ICU}$, và rút ngắn thời gian nằm viện.

\section{TÀI LIẸU THAM KHẢO}

1. Mohr FW, Morice MC, Kappetein AP, Feldman 
TE, Stahle E, Colombo A, Mack MJ, Holmes DR, Morel MA, Van Dyck N, Houle VM, Dawkins KD, Serrruys PW. Coronary artery bypass graft surgery versus percutaneous coronary intervention in patients with threevessel and left main coronary disease: 5-year follow-up of the randomized clinical Syntax trial. Lancet. 2013;381:629-638.

10.1016/S0140-6736(13)60141-5.

2. Shroyer AL, Grover FL, Hattler B, Collins JF, McDonald GO, Kozora E, Lucke JC, Baltz JH, Novitzky D. On-pump versus off-pump coronary artery bypass surgery. $\mathrm{N}$ Engl J Med. 2009;361:1827-1837. doi: 10.1056/NEJMoa0902905.

3. Hammon JW, Hines MH: Extracorporeal circulation. In Cohn LH: Cardiac Surgery in the Adult, McGraw Hill Medical, $4^{\text {th }} \mathrm{ed}$, 2012;283-329.

4. Aldea GS, Doursounian M, O'Gara P, Treanor PR, Shapira OM, Lazar HL, Shemin RJ. Heparin-bonded circuits with reduced anticoagulation protocol in primary $\mathrm{CABG}$ : $\mathrm{A}$ prospective randomized trial. Ann Thorac Surg. 1996;62:408-410.

5. Aldea GS, O'Gara P, Shapira OM, Treanor P, Osman A, Arkin C, Diamond R, Babikian V, Lazar HL, Shemin RJ. Effect of anticoagulation protocol on clinical outcomes in patients undergoing $\mathrm{CABG}$ with heparin-bonded cardiopulmonary bypass circuits. Ann Thorac
Surg. 1998;65:425-433. doi: 10.1016/S00034975(97)01347-7.

6. Ranucci M, Mazzucco A, Pressotto R, Grillone G, Casati V, Porreca L, Maugeri R, Meli M, Magagna P, Cirri S, Giomarelli P, Lorusso R, de Jong A. Heparin-coated circuits in high risk patients: A multicenter, prospective, randomized trial. Ann Thorac Surg. 1999;67:994-1000. doi: 10.1016/S00034975(99)00062-4.

7. Ovrum E, Tangen G, Tollofsrud S, Skeie B, Ringdal MAL, Istad R, Oystese R. Heparinized cardiopulmonary bypass circuits and low systemic anticoagulation: An analysis of nearly 6000 patients undergoing coronary artery bypass grafting. $\mathrm{J}$ Thorac Cardiovasc Surg. 2011;141:1145-1149. doi: 10.1016/j.jtcvs.2010.07.003.

9. Aldea GS, Mokadam NA, Melford R, Jr, Stewart D, Maynard C, Reisman M, Goss R. Changing volumes, risk profiles, and outcomes of coronary artery bypass grafting and percutaneous coronary interventions. Ann Thorac Surg. 2009;87:1828-1838. doi: 10.1016/j.athoracsur.2009.03.067.

10. Herman CR, Buth KJ, Kent BA, Hirsch GM. Clopidogrel increases blood transfusion and hemorrhagic complications in patients undergoing cardiac surgery. Ann Thorac Surg. 2010;89:397-402. doi: 10.1016/j.athoracsur.2009.10.051 